\title{
PENGEMBANGAN PERANGKAT PEMBELAJARAN MODEL LEARNING CYCLE 5E UNTUK MELATIH KEMAMPUAN BERPIKIR KRITIS SISWA PADA MATERI POKOK ALAT-ALAT OPTIK
}

\author{
Nahdia Rupawanti BR ${ }^{1)}$, Budi Jatmiko ${ }^{2)}$, Soeparman Kardi ${ }^{3)}$ \\ ${ }^{1)}$ Mahasiswa Program Studi Pendidikan Sains, Program Pascasarjana Universitas Negeri Surabaya \\ ${ }^{2), 3)}$ Dosen Pascasarjana Prodi Pendidikan Sains Universitas Negeri Surabaya \\ E-mail: nahd.raharjo@yahoo.co.id
}

\begin{abstract}
Abstrak: Penelitian ini bertujuan untuk mengembangkan perangkat pembelajaran berdasarkan model Learning Cycle $5 E$ pokok bahasan alat - alat optik untuk melatihkan kemampuan berpikir kritis siswa yang layak. Subjek penelitian adalah perangkat pembelajaran dan siswa kelas XI di MA Darul Istiqomah kabupaten Bojonegoro. Penelitian ini merupakan penelitian pengembangan dengan menggunakan model Dick and Carey. Uji coba hasil pengembangan perangkat dalam pembelajaran di kelas menggunakan one group pretest-posttest design. Teknik analisis data menggunakan deskriptif kuantitatif dan deskriptif kualititatif. Temuan dari hasil penelitian ini yaitu: Validitas perangkat pembelajaran dinyatakan valid, keterlaksanaan RPP berkategori baik; aktivitas siswa paling dominan selama pembelajaran adalah melakukan pengamatan; respon siswa terhadap pembelajaran model Learning Cycle $5 E$ dinilai baik; kemampuan berpikir kritis siswa meningkat. Kendala yang ditemui selama pembelajaran adalah waktu yang diperlukan untuk melaksanakan kegiatan pembelajaran melebihi waktu yang telah dialokasikan. Berdasarkan pembahasan hasil dan temuan-temuan, disimpulkan bahwa perangkat pembelajaran model Learning Cycle $5 E$ yang telah dikembangkan pada materi alat - alat optik, layak dipergunakan untuk melatihkan kemampuan berpikir kritis siswa.
\end{abstract}

Kata kunci: Model Learning Cycle 5E, Kemampuan Berpikir Kritis

Abstract: This Research aimed at developing instructional learning materials, particularly Optical Equipments, based on Learning Cycle 5E to facilitate the student's Critical Thinking. The research's subjects are developing instructional learning materials and students of grade XI in Islamic Senior High School Darul Istiqomah, Bojonegoro. The study used Dick's and Carey's model. The developed instructional learning material is tryouted using one group pretest-posttest design in the classroom. The study's data analysis used descriptive quantitative technique and descriptive qualitative technique. The results are obtained: developing instructional learning material validity are generally categorized as valid; RPP performing is well; the dominant activity is observation; students also have positive responses to learning model; student's critical thinking increases. The Obstacles encountered during learning is the time required to carry out learning activities exceeds from predetermined time. Based on the findings and results, it is concluded that the instructional learning materials of Learning Cycle 5E are feasible to facilitate the student's Critical Thinking.

Keywords: Learning Cycle 5E, Student's Critical Thinking

\section{PENDAHULUAN}

Salah satu faktor perkembangan suatu bangsa ditentukan oleh sumber daya manusia (SDM) yang dimiliki.Pada kenyataannya, kualitas sumber daya manusia (SDM) yang dimiliki oleh Indonesia masih berada pada level yang rendah. Menurut Human Development Index (HDI) Indonesia berada pada peringkat 108 dari 169 negara, berada jauh di bawah Malaysia (urutan 57), Brunei (urutan 37), dan Singapura (urutan 27). Masalah ini dapat diselesaikan dengan meningkatkan kualitas pendidikan di Indonesia.Mata pelajaran ilmu pengetahuan alam (IPA) sebagai mata pelajaran yang esensial dalam pendidikan memiliki peranan penting dalam peningkatan kualitas pendidikan di Indonesia. Siswa dituntut untuk memiliki kemampuan berpikir tinggi atau high order thinking skill (HOTS) untuk dapat menguasi materi pembelajaran ini. Dengan pembelajaran IPA yang menuntut kemampuan berpikir kritis yang tinggi, siswa dapat mengembangkan kemampuan berpikir logis dan kreatif yang mereka miliki untuk menjadi seorang yang dapat memecahkan masalah dengan baik.Hal inilah yang mendasari mengapa kemampuan berpikir kritis sangat diperlukan dalam kehidupan. Tetapi, pada penelitian yang berbeda, Program for International Student Assessment (PISA) pada tahun 2012 menunjukkan bahwa Indonesia berada pada peringkat 64 dengan skor rata-rata 382 dibandingkan dengan skor 
rata-rata negara lain yang mencapai 501. Penelitian ini didesain untuk mengevaluasi seberapa baik siswa dapat mengaplikasikan kemampuan berpikir secara sainstifik dalam situasi yang dihadapi. Siswa harus memiliki kemampuan berpikir kritis yang baik untuk membantu mereka dalam mengaplikasikan pengetahuan yang telah mereka miliki sebelumnya untuk memecahkan masalah mereka sendiri dalam kehidupan sehari-hari.Namun, sekali lagi PISA pun menegaskan bahwa sebesar 76 persen siswa di Indonesia tidak mencapai level 2 yang merupakan level minimal untuk keluar dari kategori low achievers.

PISA membuat suatu tingkatan kompetensi matematis yang dapat dicapai oleh siswa berdasarkan tingkat kecakapannya.Kompetensi matematis yang dibuat oleh PISA tersebut terdiri atas 6 tingkatan yang berjenjang. Berdasar hasil PISA sebagian besar siswa Indonesia berada pada level 2. Pada level ini siswa dapat menginterpretasikan dan mengenali situasi dalam konteks yang memerlukan penarikan kesimpulan secara langsung. Siswa dapat memilah informasi yang relevan dari sumber tunggal dan menggunakan penarikan kesimpulan yang tunggal.Sedangkan, hanya sedikit anak di Indonesia yang mampu mencapai level 5 dan 6 . Pada level ini siswa mampu bekerja dalam situasi yang kompleks, bekerja sesuai prosedur hingga akhirnya siswa mampu merumuskan dan mengkomunikasikan dengan tepat tindakannya dan merefleksikan dengan mempertimbangkan temuannya, interpretasinya, pendapatnya, dan ketepatan pada situasi yang nyata.Berdasarkan deskripsi ketercapaian level siswa di atas dapat disimpulkan bahwa kemampuan berpikir kritis siswa di Indonesia masih rendah.

Kemampuan berpikir kritis memiliki empat indikator, yakni kemampuan interpretasi, analisis, evaluasi, dan inferensi (Dennis, 2008). Agar dapat menguasi keempat indikator tersebut, siswa membutuhkan proses kemampuan berpikir yang melibatkan kemampuan mengevaluasi ide-ide, solusisolusi, argumen-argumen, serta fakta-fakta yang ada. Untuk dapat menguasai kemampuan berpikir kritis dengan baik maka diperlukan adanya suatu pembelajaran yang mampu melatihkan kemampuan berpikir kritis siswa secara kontinu karena itu dalam upaya melatihkan kemampuan berpikir kritis, selain merancang proses pembelajaran yang ditujukan untuk melatihkan kemampuan berpikir kritis siswa,diperlukan pula adanya sebuah perangkat pembelajaran yang mampu melatihkan kemampuan berpikir kritis siswa sebagai alat penunjang utama dalam proses pembelajaran yang diinginkan.

Sebelumnya,peneliti telah melalukan tes kemampuan berpikir kritis awal terhadap 30 siswa kelas XI di MA Darul Istiqomah, diperoleh sebanyak 10 siswa yg tuntas dalam tes tersebut atau dengan kata lain sebesar $34 \%$ siswa yang tuntas dengan KKM yang ditentukan yakni 70. Nilai ketuntasan yang rendah ini menunjukkan bahwa kemampuan berpikir kritis siswa juga masih rendah. Oleh karena itu, guru diharapkan mampu memberikan proses pembelajaran yang dapat melatih kemampuan berpikir kritis siswa dengan adanya inovasi dalam pembelajaran fisika yang dapat memicu keterlibatan aktif siswa, dengan tujuan agar siswa lebih mudah memahami konsep fisika yang diberikan di dalam kelas dan dapat menerapkan langsung konsep fisika tersebut dalam kehidupan sehari-hari.

Adanya proses pembelajaran yang baik tidak akan lepas dari perangkat pembelajaran yang tepat yakni perangkat pembelajaran yang disusun dan dipilih sesuai dengan kompetensi yang akan dikembangkan. Perangkat pembelajaran sendiri merupakan wujud persiapan guru sebelum melakukan proses pembelajaran. Perangkat pembelajaran juga diartikan sebagai sejumlah bahan, alat, media, dan pedoman yang akan digunakan dalam proses pembelajaran. Tujuan penyusunan perangkat itu sendiri adalah agar segala sesuatu yang telah direncanakan dapat tercapai. Menurut Peraturan Pemerintah (PP) Nomor 19 Tahun 2005 tentang Standar Nasional Pendidikan pasal 20, "Perencanaan proses pembelajaran meliputi silabus dan rencana pelaksanaan pembelajaran yang memuat sekurang - kurangnya tujuan pembelajaran, materi ajar, metode pengajaran, sumber belajar, dan penilaian hasil belajar. Selain sebuah perangkat pembelajaran yang baik, diperlukan pula dengan model pembelajaran yang sesuai dengan materi pembelajaran sehingga tujuan akhir dalam pembelajaran dapat tercapai.

Pada tahun 2013, Erie melakukan penelitian dengan mengangkat learning cycle $5 E$ sebagai model pembelajaran untuk meningkatkan penguasaan konsep dan kemampuan berpikir kritis siswa.Model learning cycle $5 E$ sendiri merupakan model pembelajaran berbasis pada teori pembelajaran konstruktivisme. Model pembelajaran ini terdiri atas lima fase, yakni Engage, Explore, Explain, Elaborate dan Evaluate (Bybee, 2006). Setiap fase pada model learning cycle $5 E$ memberikan kesempatan siswa untuk bertanya, mengumpulkan, merekam, dan merefleksikan data yang mereka peroleh untuk membentuk teori serta penjelasan yang mereka buat sendiri. Dengan kata lain, siswa dituntut untuk berpikir secara kritis pada tiap fasenya.

Hal tersebut di atas yang memperkuat alasan bagi peneliti untuk berupaya mengembangkan perangkat pembelajaran model learning cycle $5 E$ agar dapat melatihkan kemampuan berpikir kritis siswa.

Berdasarkan latar belakang di atas, rumusan masalah dalam penelitian ini adalah "Bagaimana kelayakan perangkat pembelajaran menggunakan model learning cycle $5 E$ untuk melatih kemampuan berpikir 
kritis siswa SMA". Pada penelitian ini, indikator kelayakan perangkat pembelajaran model learning cycle $5 E$ ini adalah validitas, kepraktisan dan keefektifan dari perangkat pembelajaran. Adapun pertanyaan penelitian dapat dirinci sebagai berikut :

1. Bagaimanakah kevalidan perangkat pembelajaran menggunakan model learning cycle 5 Euntuk melatihkemampuan berpikir kritis siswa ?

a. Bagaimanakah kevalidan RPP menggunakan model learning cycle $5 E$ untuk melatih kemampuan berpikir kritis siswa?

b. Bagaimanakah kevalidan LKS menggunakan model learning cycle $5 E$ untuk melatih kemampuan berpikir kritis siswa?

c. Bagaimanakah kevalidan instrument penelitian menggunakan model learning cycle $5 E$ untuk melatih kemampuan berpikir kritis siswa ?

2. Bagaimanakah kepraktisan perangkat pembelajaran menggunakan model learning cycle $5 E$ untuk melatih kemampuan berpikir kritis siswa?

a. Bagaimanakah keterlaksanaan RPP menggunakan model learning cycle $5 E$ untuk melatih kemampuan berpikir kritis siswa?

b. Bagaimanakah kendala-kendala yang dihadapi selama menerapkan perangkat pembelajaran menggunakan model learning cycle $5 E$ untuk melatih kemampuan berpikir kritis siswa ?

c. Bagaimanakah aktivitas siswa yang dibelajarkan melalui pengembangan perangkat pembelajaran menggunakan model learning cycle $5 E$ untuk melatih kemampuan berpikir kritis siswa?

3. Bagaimanakah keefektifan perangkat pembelajaran menggunakan model learning cycle $5 E$ untuk melatih kemampuan berpikir kritis siswa?

a. Bagaimanakah kemampuan berpikir kritis siswa setelah menggunakan pengembangan perangkat pembelajaran menggunakan model learning cycle $5 E$ ?

b. Bagaimanakah respon siswa terhadap pengembangan perangkat pembelajaran menggunakan model learning cycle $5 E$ untuk melatih kemampuan berpikir kritis siswa?

\section{METODE PENELITIAN}

Penelitian ini merupakan penelitian pengembangan (developmental research) karena mengembangkan perangkat pembelajaran dengan model Learning Cycle $5 E$ untuk melatihkan kemampuan berpikir kritis pada siswa. Gejala-gejala yang diamati adalah hasil belajar kemampuan berpikir kritis siswa, keterlaksanaan pengelolaan pembelajaran, dan respons siswa yang terjadi selama pembelajaran. Perangkat pembelajaran yang dikembangkan berupa Rencana Pelaksanaan pembelajaran (RPP), Buku Siswa, LKS, dan Tes Kemampuan Berpikir Kritis.
Penelitian ini dilakukan pada semester ganjil, tahun ajaran 2016-2017 di MA Darul Istiqomah Kepoh Baru Bojonegoro dengan subjek penelitiannya adalah siswa Kelas X.1, X.2, dan X.3 pada materi Alat - Alat Optik. Penelitian ini dilaksanakan dalam 2 (dua) tahap, yaitu tahap pertama merupakan tahap pengembangan perangkat pembelajaran yang dilanjutkan dengan ujicoba terbatas atau ujicoba I, dan tahap kedua merupakan tahap implementasi perangkat pembelajaran

Model pengembangan perangkat pembelajaran yang digunakan dalam penelitian ini adalah model Dick and Carey. Rancangan uji coba yang dipergunakan baik dalam uji coba I maupun uji coba II adalah rancangan One Group Pretest-Posttest Desaign, yaitu desain penelitian yang diterapkan pada suatu kelompok, tanpa kelompok banding (kontrol) dengan notasi sebagai berikut:

\begin{tabular}{|lll|}
\hline $\mathbf{U}_{1}$ & $\mathbf{X}$ & $\mathrm{U}_{2}$ \\
\hline
\end{tabular}

Keterangan:

$\mathbf{U}_{\mathbf{1}}=\mathrm{Uji}$ awal atau pretest untuk mengetahui kemampuan berpikir kritis siswa sebelum diberi perlakuan

$\mathbf{X}=$ Perlakuan, yaitu proses pembelajaran Learning Cycle 5

$\mathbf{U}_{\mathbf{2}}=\mathrm{Uji}$ akhir atau posttest untuk mengetahui kemampuan berpikir kritis siswa setelah diberi pembelajaran Learning Cycle $5 E$

Penelitian ini menggunakan tiga cara pengumpulan data yaitu melalui tes tertulis, memberikan angket, dan lembar observasi. Pengumpulan data dilalui dengan menentukan sumber data, jenis data dan teknik pengumpulan data serta instrumen perolehan data. Secara lengkap dapat diamati dari Tabel 1.

Tabel 1. Teknik Pengumpulan Data

\begin{tabular}{|c|c|c|c|}
\hline $\begin{array}{l}\text { Sumber } \\
\text { data }\end{array}$ & Jenis Data & $\begin{array}{l}\text { Teknik } \\
\text { Pengum- } \\
\text { pulan data }\end{array}$ & Instrumen \\
\hline $\begin{array}{l}\text { Siswa } \\
\text { dan } \\
\text { guru }\end{array}$ & $\begin{array}{lr}\text { Aktivitas siswa } \\
\text { dan guru selama } \\
\text { PBM dan } \\
\text { keterlaksanaan } \\
\text { pembelajaran } \\
\text { Learning Cycle } \\
\text { 5E }\end{array}$ & observasi & $\begin{array}{l}\text { Lembar } \\
\text { observasi } \\
\text { aktivitas } \\
\text { guru dan } \\
\text { siswa } \\
\text { selama } \\
\text { PBM }\end{array}$ \\
\hline
\end{tabular}

Adapun instrument serta analisis yang digunakan untuk mengumpulkan data dalam penelitian ini adalah sebagai berikut :

\section{A. Lembar Validasi Perangkat Pembelajaran}

Kelayakan perangkat pembelajaran diukur dari kualitasnya dengan menggunakan lembar validasi perangkat pembelajaran. Lembar validasi perangkat pembelajaran adalah lembar untuk memvalidasi perangkat yang dikembangkan, dan dilaksanakan oleh validator. Analisis hasil data validasi perangkat 
pembelajaran disajikan dalam skala penilaian berikut :

Tabel 2. Skala Penilaian Perangkat

\begin{tabular}{|l|c|l|}
\hline Nilai & Skala & Keterangan \\
\hline Baik & 4 & $\begin{array}{l}\text { Kualitas baik, mudah dipahami, } \\
\text { sesuai dengan konteks penjelasan }\end{array}$ \\
\hline $\begin{array}{l}\text { Cukup } \\
\text { baik }\end{array}$ & 3 & $\begin{array}{l}\text { Kualitas baik, mudah dipahami, } \\
\text { perlu disempurnakan konteks } \\
\text { penjelasan }\end{array}$ \\
\hline $\begin{array}{l}\text { Kurang } \\
\text { baik }\end{array}$ & 2 & $\begin{array}{l}\text { Kualitas baik, sulit dipahami, perlu } \\
\text { disempurnakan dengan konteks } \\
\text { penjelasan }\end{array}$ \\
\hline $\begin{array}{l}\text { Tidak } \\
\text { baik }\end{array}$ & 1 & $\begin{array}{l}\text { Kualitas tidak baik, sulit dipahami, } \\
\text { perlu disempurnakan konteks } \\
\text { penjelasan }\end{array}$ \\
\hline
\end{tabular}

Diadaptasi dari Ratumanan dan Laurends (2006)

\section{B. Lembar Pengamatan Keterlaksanaan RPP}

Lembar ini digunakan untuk mengumpulkan data tentang keterlaksanaan tahapan-tahapan pembelajaran melalui model pembelajaran Learning Cycle 5E sesuai dengan yang tercantum dalam RPP. Pengisian lembar pengamatan dilakukan dengan memberi tanda cek $(\sqrt{ })$ pada kolom yang sesuai dengan tahapan pembelajaran yang dilaksanakan oleh guru, serta memberikan skor berdasarkan petunjuk penilaian.

Penilaian kualitas keterlaksanaan proses belajar mengajar ditentukan dengan menghitung rata-rata skor penilaian yang diberikan kedua pengamat. Sedangkan persentase keterlaksanaan pembelajaran yang dilakukan guru selama kegiatan belajar mengajar berlangsung ditentukan dengan membandingkan jumlah aspek yang terlaksana dengan jumlah seluruh aspek pada rancangan pembelajaran Learning Cycle 5E yang dilakukan guru selama kegiatan belajar mengajar dikalikan 100\%. Rumus yang digunakan sebagai berikut:

$$
\mathrm{P}=\frac{\sum \boldsymbol{A}}{\sum \boldsymbol{B}} \times \mathbf{1 0 0 \%}
$$

Keterangan:

$$
\begin{aligned}
& \mathrm{P}=\text { Persentase } \\
& \sum \mathrm{A}=\text { Jumlah skor yang diperoleh } \\
& \sum \mathrm{B}=\text { Total jumlah skor }
\end{aligned}
$$

(Arikunto, 2009)

Persentase keterlaksanaan fase menggunakan kriteria sebagai berikut:

$$
\begin{array}{lll}
\mathrm{P}=0 \%-24 \% & : & \text { tidak terlaksana } \\
\mathrm{P}=25 \%-49 \% & : & \text { terlaksana kurang } \\
\mathrm{P}=50 \%-74 \% & : & \text { terlaksana baik } \\
\mathrm{P}=75 \%-100 \% & : \text { terlaksana sangat baik }
\end{array}
$$

\section{Lembar Pengamatan Aktivitas Siswa}

Lembar ini digunakan untuk mengamati aktivitas siswa selama menerapkan pembelajaran IPA dengan menggunakan perangkat pembelajaran yang telah dikembangkan. Data yang diperoleh selanjutnya dianalisis deskriptif kuantitatif dengan menggunakan rumus percentage of agreement sebagai berikut:

$$
P=\frac{\sum K}{\sum_{N}} \times 100 \%
$$

Keterangan:

$\mathrm{P}=$ Persentase aktivitas siswa

$\sum \mathrm{R}=$ Jumlah frekuensi tiap aktivitas yang muncul

$\sum \mathrm{N}=$ Jumlah total frekuensi aktivitas.

\section{Lembar Angket Respon Siswa}

Angket respon siswa digunakan untuk mengukur pendapat siswa terhadap ketertarikan, perasaan senang dan keterkinian, serta kemudahan memahami komponen-komponen: materi/isi pelajaran, format materi ajar, kegiatan dalam LKS, suasana belajar, cara guru mengajar dan pendekatan pembelajaran yang digunakan. Angket respon siswa diberikan pada siswa setelah seluruh KBM selesai.

Data yang diperoleh kemudian dianalisis secara deskriptif kuantitatif dengan persentase yaitu jumlah respon siswa dibagi jumlah keseluruhan respon dikalikan $100 \%$. Rumus perhitungan respon siswa sebagai berikut:

$$
\mathrm{P}=\frac{\sum \pi}{\sum N} \times 100 \%
$$

Keterangan:

$$
\begin{aligned}
& \mathrm{P}=\text { Persentase } \\
& \sum \mathrm{R}=\text { Jumlah respon } \\
& \sum \mathrm{N}=\text { jumlah keseluruhan respon. }
\end{aligned}
$$

\section{E. Instrumen Tes Kemampuan Berpikir Kritis}

Instrumen tes kemampuan berpikir kritis digunakan untuk mengukur kemampuan berpikir kritis siswa pada aspek kognitif berupa kemampuan interpretasi, kemampuan analisis, kemampuan evaluasi, dan kemampuan inferensi. Tes kemampuan berpikir kritis menggunakan bentuk pilihan ganda sebanyak 15 soal dan uraian sebanyak 5 soal. Ketuntasan individual dari hasil tes kognitif inilah yang akan digunakan sebagai acuan kemampuan berpikir kritis siswa. Ketuntasan individual sendiri dianalisis dengan membandingkan hasil yang diperoleh siswa dengan Kriteria Ketuntasan Minimal $(\mathrm{KKM}=70)$ yang telah ditetapkan oleh sekolah. Nilai siswa secara individu adalah jumlah skor yang diperoleh siswa dibagi skor maksimum dan dikali 100

$$
\begin{array}{ll}
T_{\text {individuai }}=\left(\frac{\Sigma S_{s}}{\left.\Sigma S_{\text {makl }}\right)} \times 100\right. \\
\text { Keterangan: } \\
T_{\text {individuai }}: \text { ketuntasan individual } \\
\Sigma_{s} \quad: \text { jumlah skor perolehan siswa } \\
\Sigma^{S_{\text {maks }}} \quad \text { : jumlah skor maksimum }
\end{array}
$$

Sedangkan untuk mengetahui seberapa besar pengaruh pembelajaran model Learning Cycle $5 E$ terhadap kemampuan berpikir kritis siswa, dilakukan analisis statistik inferensial berupa analisis $N$-gain 
score dengan rumus sebagai berikut:

$$
\begin{aligned}
& (g)=\frac{\left.\left(<S_{\text {post }}>-<S_{\text {pre }}\right\rangle\right)}{\left.\left(100-<S_{\text {pre }}\right\rangle\right)} \\
& \text { dengan }(\mathrm{g}) \quad=\text { nilai Gain } \\
& \text { Spost = nilai post-test } \\
& \text { Spre } \quad=\text { nilai } \text { pre-test } \\
& \text { Smax = nilai maksimal }
\end{aligned}
$$

Kriteria skor Gains menurut Hake (1999) terbagi atas 3 tingkatan yaitu:

$$
\begin{array}{ll}
\text { g-tinggi } & =(\mathrm{g}) \geq 0,7 \\
\text { g-sedang } & =0,7>(\mathrm{g}) \geq 0,3 \\
\text { g-rendah } & =(\mathrm{g})<0,3
\end{array}
$$

\section{F. Lembar Pengamatan Kendala Pembelajaran}

Instrumen ini merupakan instrumen yang digunakan untuk mengidentifikasi hambatan-hambatan yang dihadapi guru dalam penerapan pembelajaran model Learning Cycle $5 E$ yang diamati oleh dua orang pengamat.

\section{HASIL PENELITIAN DAN DISKUSI}

A. Validasi Perangkat Pembelajaran

Perangkat Pembelajaran yang divalidasi terdiri dari Rencana Pelaksanaan Pembelajaran (RPP), Buku Ajar Siswa (BAS), Lembar Kegiatan Siswa (LKS) dan Tes Kemampuan Berpikir Kritis. Hasil validasi dari perangkat yang telah dikembangkan adalah sebagai berikut :

Tabel 3. Validasi Perangkat pembelajaran

\begin{tabular}{|l|l|l|}
\hline Instrumen Pembelajaran & $\begin{array}{c}\text { Skor rata - } \\
\text { rata }\end{array}$ & Kategori \\
\hline RPP & 3.45 & VALID \\
\hline LKS & 3.54 & VALID \\
\hline BAS & 3.00 & VALID \\
\hline Tes KBK & 3.60 & VALID \\
\hline
\end{tabular}

Berdasarkan tabel diatas, secara umum hasil validasi dari perangkat yang telah dikembangkan memiliki kategori valid dan dapat digunakan dengan sedikit revisi. Hasil penilaian validator menunjukkan bahwa RPP yang dikembangkan dengan skor rata - rata 3.45 telah layak dijadikan panduan guru dalam mengelola pembelajaran pada materi pokok alat - alat opik. Penyusunan RPP ini berpedoman pula pada PP nomor 19 tahun 2005 tentang BSNP pada pasal 20 yang menyebutkan bahwa RPP sekurang-kurangnya memuat tujuan pembelajaran, materi ajar, metode pengajaran, sumber belajar dan penilaian hasil belajar. Dalam setiap fase - fase yang ada dalam RPP yang dikembangkan telah disesuai dengan indikator - indikator kemampuan berpikir kritis yang ingin dicapai. Pada fase explanation siswa akan mencoba untuk menjelaskan istilah dan simbol - simbol yang digunakan dengan bahasanya sendiri. Dalam hal ini siswa akan dituntut untuk memiliki kemampuan interpretasi serta analisis yang baik sehingga dalam fase tersebut secara tidak langsung siswa akan melatih kemampuan berpikir kritis. Sedangkan pada fase evaluation siswa harus mampu menilai hasil belajar mereka sendiri sehingga pada fase ini siswa melatih kemampuan inferensi dimana siswa mampu membuat generalisasi atau membuat kesimpulan dari permasalah yang ada.

Hasil validasi menunjukkan bahwa LKS yang dikembangkan layak untuk digunakan. Adapun aspek penilaian pada LKS meliputi aspek kelengkapan, kelayakan isi, dan prosedur. Tujuan penyusunan LKS diantaranya membantu siswa dalam melakukan praktikum sebagai bagian dari proses belajar. LKS yang telah dikembangkan pun telah dirancang untuk membantu menstimulasi kemampuan berpikir kritis siswa. Buku siswa yang telah dikembangkan dinilai valid dengan skor rata - rata 3.00. Buku siswa telah disusun secara sistematis dengan mensusuaikan setiap fase - fase yang ada pada model pembelajaran Learning Cycle 5E. Hal ini bertujuan untuk memudahkan siswa dalam memahami pengetahuan-pengetahuan faktual yang disajikan secara bertahap dari konsep-konsep yang sederhana berkembang menuju ke konsep-konsep yang lebih kompleks pada materi alat - alat optic sehingga diharapkan mampu membantu meningkatkan kemampuan berpikir kritis siswa.

Hasil validasi yang sama pun ditunjukkan oleh instrument tes kemampuan berpikir kritis. Tes kognitif ini meliputi 15 soal pilihan ganda serta 5 soal essay yang dirancang sesuai dengan indikator - indikator kemampuan berpikir kritis yang ingin dicapai. Tes kemampuan berpikir kritis yang dikembangkan dianggap layak untuk digunakan dengan skor rata- rata 3.60 .

\section{B. Kepraktisan Perangkat Pembelajaran}

1. Keterlaksaan Rencana Pelaksanaan Pembelajaran

Keterlaksaan RPP diamati oleh dua pengamat dengan instrumen pengamatan yang telah ditentukan. Keterlaksaan RPP diamati pada ketiga kelas dengan masing - masing kelas tiga kali pertemuan selama 45 menit setiap pertemuannya. Adapun aspek yang diamati meliputi pendahuluan, kegiatan inti, dan penutup. Hasil dari pengamatan keterlaksanaan pembelajaran pada ketiga kelas tersebut tercantum dalam Tabel 4. berikut :

Tabel 4. Keterlaksaan RPP

\begin{tabular}{|c|c|c|c|c|c|}
\hline Kelas & RPP I & RPP II & RPP III & Rata - rata & Kategori \\
\hline X.1 & 3.51 & 3.66 & 3.66 & 3.64 & Baik \\
\hline X.2 & 3.69 & 3.61 & 3.64 & 3.64 & Baik \\
\hline X.3 & 3.38 & 3.61 & 3.37 & 3.57 & Baik \\
\hline
\end{tabular}

Tabel diatas memperlihatkan skor hasil penilaian keterlaksaan RPP. Dari hasil skor tersebut menunjukkan bahwa RPP yang dikembangkan memiliki kategori baik dan dapat dilaksanakan dengan baik pula. untuk... 


\section{Kendala dan Solusi}

Dalam pelaksanaan pembelajaran dengan perangkat yang telah dikembangkan ditemui beberapa kendala. Kendala - kendala tersebut kemudian didiskusikan sehingga mendapatkan solusi dari kendala yang dihadapi. Kendala serta solusi tersebut ditunjukkan pada tabel berikut :

Tabel 5. Hasil Pengamatan Kendala dan Solusi

\begin{tabular}{|l|l|}
\hline Kendala & Solusi \\
\hline $\begin{array}{l}\text { Jumlah alat } \\
\text { praktikum yang } \\
\text { kurang memenuhi }\end{array}$ & $\begin{array}{l}\text { Menggunakan alat } \\
\text { praktikum dengan } \\
\text { bergantian secara tertib } \\
\text { dengan memaksimalkan } \\
\text { waktu yang ada }\end{array}$ \\
\hline $\begin{array}{l}\text { Lemahnya jaringan } \\
\text { internet di sekolah } \\
\text { sehingga menyulitkan } \\
\text { siswa dalam } \\
\text { menggali informasi } \\
\text { dari berbagai sumber }\end{array}$ & $\begin{array}{l}\text { Menambah jaringan internet } \\
\text { lokal mandiri dari siswa } \\
\text { (wifi lokal) }\end{array}$ \\
\hline $\begin{array}{l}\text { Waktu yang } \\
\text { diperlukan untuk } \\
\text { melaksanakan } \\
\text { kegiatan } \\
\text { pembelajaran } \\
\text { melebihi waktu yang } \\
\text { telah dialokasikan. }\end{array}$ & $\begin{array}{l}\text { Mengorganisir kembali } \\
\text { alokasi waktu sehingga } \\
\text { semua kegiatan } \\
\text { pembelajaran terlaksana, dan } \\
\text { menambahkan alokasi waktu } \\
\text { jika memungkinkan }\end{array}$ \\
\hline
\end{tabular}

\section{Aktivitas siswa}

Aktivitas siswa diamati selama proses pembelajaran berlangsung. Pengamatan dilakukan oleh dua orang pengamat. Setiap aktivitas siswa dicatat. Adapun hasil rekapitulasi aktivitas siswa selama pembelajaran disajikan dalam gambar berikut :

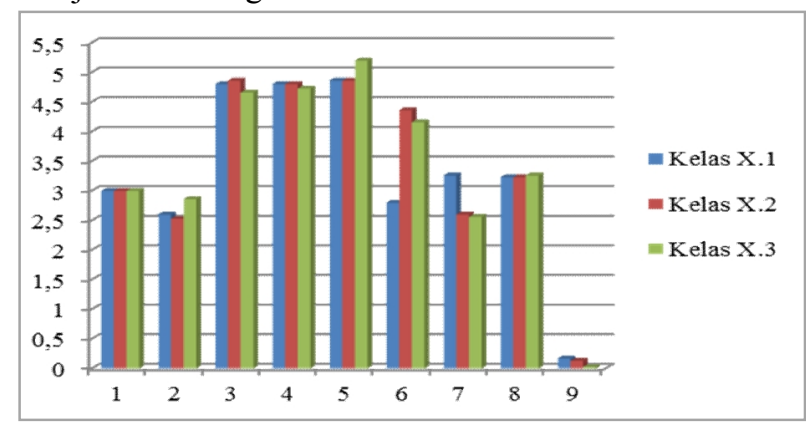

Gambar 1. Aktivitas Siswa

Keterangan :

$1=$ Memperhatikan penjelasan guru

2 = Membaca atau mencari informasi materi ajar yang sesuai

3 = Melakukan percobaan sesuai dengan panduan LKS

$4=$ Melakukan pengamatan sesuai prosedur di LKS

5 = Mencatat data hasil pengamatan

$6=$ Menjawab pertanyaan guru

7 = Menyampaikan pendapat/

Mengkomunikasikan informasi kepada kelas/guru

$8=$ Bertanya

9 = Perilaku tidak relevan
Berdasarkan tabel diatas, secara umum aktivitas siswa selama pembelajaran dikategorikan baik. Aktivitas yang lebih dominan dalam pembelajaran adalah melakukan pengamatan dan mencatat data hasil pengamatan dan yang paling rendah perilaku yang tidak relevan dengan kegiatan pembelajaran.

\section{Kefektifan Perangkat Pembelajaran}

1. Kemampuan Berpikir Kritis Siswa

Kemampuan berpikir kritis siswa diukur melalui tes koginitif yang dirancang sesuai dengan indikator indikator kemampuan berpikir kritis siswa. Hasil pretest dan posttes digunakan sebagai dasar acuan penentu kemampuan berpikir kritis siswa awal dan kemampuan berpikir kritis siswa setelah menggunakan pembelajaran. Selain digunakan untuk menentukan kemampuan berpikir kritis siswa awal, hasil presets dapat digunakan untuk mengetahui normalitas dan homogenitas populasi. Berikut hasil uji normalitas pada populasi

Tabel 6. Hasil Perhitungan Uji Normalitas

\begin{tabular}{|c|c|c|c|c|}
\hline Kelas & A & Dk & $\chi_{\text {tabel }}^{2}$ & $\chi_{\text {hitung }}^{2}$ \\
\hline X.1 & \multirow[t]{3}{*}{0,05} & \multirow[t]{3}{*}{6} & \multirow[t]{3}{*}{11,1} & 2,83 \\
\hline X.2 & & & & 2,61 \\
\hline X.3 & & & & 3,59 \\
\hline
\end{tabular}

Populasi dapat dikatakan berdistribusi normal, jika $\chi_{\text {hitung }}^{2}<\chi_{\text {tabel. }}^{2}$ Berdasarkan Tabel 6 di atas dapat disimpulkan bahwa populasi berdistribusi normal dengan taraf signifikan $\alpha=0,05$ atau dengan taraf kepercayaan sebesar $95 \%$.

Uji homogenitas dilakukan dengan menggunakan uji Bartlett. Data yang diuji adalah data pretest masingmasing kelas Hasil uji homogenitas untuk populasi dapat dituliskan dalam tabel 7. sebagai berikut

Tabel 7. Hasil Perhitungan Uji Homogenitas

\begin{tabular}{|c|c|c|c|c|c|c|}
\hline Kelas & $\mathbf{n}_{\mathrm{i}}$ & $\mathrm{S}_{1}^{2}$ & $S_{g a b}$ & B & $\mathbf{X}^{2}(1-0,08)$ & $\mathrm{X}^{2}$ hitung \\
\hline X.1 & 30 & 47.126 & \multirow[t]{3}{*}{66.33} & \multirow[t]{3}{*}{158.49} & \multirow[t]{3}{*}{15.5} & \multirow[t]{3}{*}{2.09} \\
\hline $\mathrm{X} .2$ & 30 & 73.697 & & & & \\
\hline $\mathrm{X} .3$ & 30 & 78.166 & & & & \\
\hline
\end{tabular}

Populasi dapat dikatakan homogen, jika $\chi^{2}$ hitung $<$ $\chi^{2}$ tabel. Berdasarkan tabel diatas dapat disimpulkan bahwa populasi homogen dengan taraf signifikan $\alpha=$ 0,05 dan dengan taraf kepercayaan sebesar 95\%. Untuk mengetahui ada tidaknya pengaruh pembelajaran yang digunakan terhadap kemampuan berpikir kritis siswa maka dilakukan uji-t. Berikut adalah hasil uji-t yang dilakukan pada masing - masing sampel.

Tabel 8. Hasil Uji-t Berpasangan

\begin{tabular}{|l|l|l|}
\hline Kelas & thitung & $t_{\text {tabel }}$ atau $\left.\mathrm{t}_{(1-1 / 2} \alpha\right)$ \\
\hline Kelas X.1 & 4.47 & 2.00 \\
\hline Kelas X.2 & 6.71 & 2.00 \\
\hline Kelas X.3 & 9.22 & 2.00 \\
\hline
\end{tabular}


Hipotesis yang diajukan $\mathrm{H}_{0}: \mu_{1}=\mu_{2}$, kemampuan berpikir kritis siswa sebelum dan sesudah menggunakan model Learning Cycle $5 E$ adalah sama, $\mathrm{H}_{1}: \mu_{1} \neq \mu_{2}$, kemampuan berpikir kritis siswa sebelum dan sesudah menggunakan model Learning Cycle $5 E$ adalah berbeda. Kriteria penarikan hipotesis yaitu terima $\mathrm{H}_{\mathrm{o}}$ jika $-\mathrm{t}_{(1-1 / 2 \alpha)}<\mathrm{t}_{\text {hitung }}<\mathrm{t}_{(1-1 / 2 \alpha)}$ atau $-\mathrm{t}_{\text {tabel }}<\mathrm{t}_{\text {hitung }}$ $<\mathrm{t}_{\text {tabel }}$ dan tolak $\mathrm{H}_{\mathrm{o}}$ untuk harga - harga $\mathrm{t}$ yang lain, dengan derajat kebebasan untuk derajat distribusi $t$ adalah $\left(\mathrm{n}_{1}+\mathrm{n}_{2}-2\right)$ dengan peluang $\left(\begin{array}{lll}1-1 / 2 & \alpha\end{array}\right)$. Berdasarkan nilai uji-t berpasangan menunjukkan bahwa kemampuan berpikir kritis siswa sebelum dan sesudah menggunakan model Learning Cycle $5 E$ adalah berbeda.

Perhitungan N-Gain dilakukan untuk mengetahui seberapa besar peningkatan kemampuan berpikir kritis siswa setelah pembelajaran. Berikut N-gain skor rata rata pada masing - masing kelas

Tabel 9. N-Gain skor rata - rata

\begin{tabular}{|l|c|l|}
\hline Kelas & N-Gain skor rata - rata & Kategori \\
\hline X.1 & 0.63 & Sedang \\
\hline X.2 & 0.71 & Tinggi \\
\hline X.3 & 0.84 & Tinggi \\
\hline
\end{tabular}

Berdasarkan tabel diatas dapat diketahui bahwa terdapat peningkatan yang signifikan pada kemampuan berpikir kritis siswa setelah pembelajaran dilakukan.

\section{Respon Siswa}

Respon siswa diperoleh dengan memberikan angket respon kepada seluruh siswa setelah mengikuti kegiatan pembelajaran. Hasil respon siswa tercantum dalam Gambar 2. sebagai berikut :

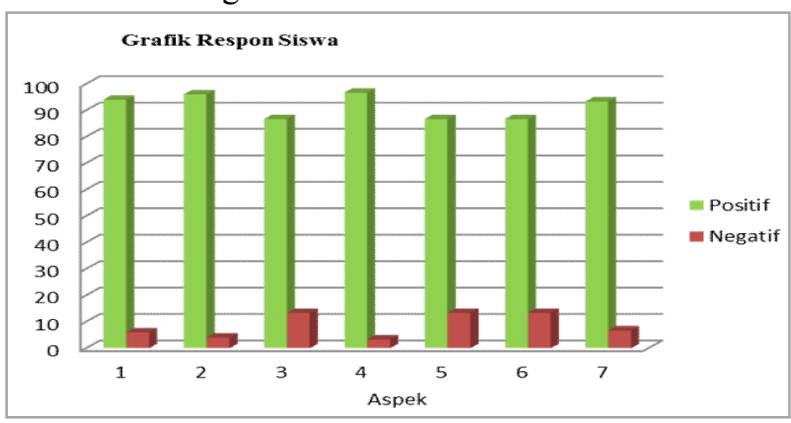

Gambar 2. Respon Siswa

Berdasarkan diagram diatas dapat diketahui bahwa siswa memberikan respon positif terhadap pembelajaran Learning Cycle $5 E$ yang telah dilaksanakan dan siswa juga merasa tertarik terhadap perangkat pembelajaran Learning Cycle $5 E$ yang telah dikembangkan.

\section{KESIMPULAN}

\section{A. Simpulan}

Pengembangan perangkat pembelajaran telah memenuhi syarat kevalidan, kepraktisan, dan keefektifan sehingga dapat disimpulkan bahwa perangkat pembelajaran model Learning Cycle $5 E$ untuk melatihkan kemampuan berpikir kritis siswa layak untuk diterapkan dalam pembelajaran.

\section{B. Saran}

1. Dalam menerapkan pembelajaran Learning Cycle $5 \mathrm{E}$ dengan menggunakan perangkat yang dikembangkan, guru hendaknya mengelola waktu dengan baik karena banyak kegiatan yang harus siswa lakukan secara mandiri.

2. Sekolah hendaknya memiliki fasilitas pendukung pembelajaran seperti komputer, laboratorium serta jaringan internet yang baik sehingga mempermudah siswa dalam menggali informasi.

3. Kemampuan berpikir kritis perlu dilatihkan secara berkelanjutan pada setiap pembelajaran IPA.

\section{REFERENSI}

Abruscato. (1992). Teaching Children Science, A Discovery Approach, Third Edition. Needham Heights: Allyin and Bacon.

Arends, R. I. 2008. Classroom Instruction and Management. New York : McGraw-Hill Company.

Arikunto, S. (2010). Prosedur Penelitian. Jakarta : Rineka Cipta.

BSNP. (2007). Permendiknas Nomor 20 Tahun 2007 Tentang Standar Penilaian Pendidikan. Jakarta: BSNP.

Bybee, R. W., Taylor, J.A., Gardner A., Scotter, P. V., Powell, J.C., Westbrook, A. \& andes, N. (2006). The basic 5E instructional model: origins and effectiveness. Office Of Science Education National Institutes Of Health. 1-80.

Ennis, R.H. (1995). Critical Thinking. Prentice-Hall, Inc. The United State of America.

Filsaime, Dennis K. (2008). Menguak Rahasia Berpikir Kritis dan Kreatif. Jakarta : Prestasi Pustaka Publisher.

Hake, R.R. (1999). Analyzing Change/Gain Scores. American Educational Research Association's Division D, Measurement and Research Methodology. $\quad$ http://lists.asu.edu/cgibin/wa?A2=ind9903\&L=aera- $\quad \mathrm{d} \& \mathrm{P}=\mathrm{R} 6855$ > . Diunduh pada 23 Desember 2013.

Ibrahim, M. (2012). Pengembangan Perangkat Pembelajaran. Surabaya : Departemen

Ratumanan, T.G dan Laurens T. (2011). Penilaian Hasil Belajar pada Tingkat Satuan Pendidikan. Surabaya:Universitas Negeri Surabaya Press.

Riduwan. (2010. Belajar Mudah Penelitian. Bandung : Alfabeta.

Slavin, R. E. (2006). Educational Psychology: Teory and Practice $8^{\text {th }}$ ed. Boston: Pearson. 
Sudjana, Nana. (2011). Dasar-Dasar Proses Belajar Mengajar. Bandung : Sinar Baru Algensindo.

Suharsimi, A. (2002). Dasar-dasar Evaluasi Pendidikan (Edisi Revisi). Jakarta: Bumi Aksara.

Suharsimi, A. (2010). Prosedur Penelitian Suatu Pendekatan Praktik. Jakarta: Rineka Cipta.

Susanto. (2007). Pengembangan KTSP Dengan Perspektif Manajemen Misi. Surabaya: Mata Pena.

Susilana, Rudi, \& Cepi Riyana. (2007). Media Pembelajaran. Bandung: CV Wacana Prima.

Suyono dan Hariyanto. (2007). Belajar dan Pembelajaran. Bandung : Remaja Rosdakarya:.

Tuckman, Bruce, W. (1978). Conducting Educational Research. San Diego: Harcourt Brace
Jovanonich, Publishers

duh pada 15 Desember 2013.

Wiyanto. (2006). Pengembangan Kemampuan Merancang Kegiatan Laboratorium Fisika Berbasis Inkuiri Bagi Mahasiswa Calon Guru. Jurnal Pendidikan dan Pengajaran IKIP Negeri Singaraja. Diseminarkan pada April 2006.

Zohar, Anat, and Yehudit J. Dori. (2003). Higher Order Thinking Skills and Low-Achieving Students: Are They Mutually Exclusive?. The Journal of The Learning Sciences. Israel: Hebrew University. 